\title{
Ecologization of the Development Management of the Mining Regions of Russia
}

\author{
Irina Kolechkina ${ }^{1,}{ }^{*}$ Irina Verchagina $^{1}$, Elena Eltsova $^{1}$, and Mariana Petrova ${ }^{2}$ \\ ${ }^{1}$ T.F. Gorbachev Kuzbass State Technical University, Belovo branch, 65264466 Ilyica st. 32, Belovo, \\ Russia \\ ${ }^{2}$ St. Cyril and St. Methodius University of Veliko Tarnovo, Veliko Tarnovo, Bulgaria
}

\begin{abstract}
The article presents the results of the analysis of the development strategies of the mining regions of Russia for the environmental measures. The objectives of the strategic development of the regions, the inclusion of environmental development measures in the management system are studied, the content of the strategies of mining regions in relation to eliminating existing environmental damage and the implementation of measures to conserve forests and natural systems is studied.
\end{abstract}

\section{Introduction}

Environmental aspects related to the performance of mining enterprises have been the focus of attention of researchers since the second half of the last century. It is noted that efforts to improve the environmental situation often do not lead to the results that were expected [1], which requires changes in approaches to environmental management

Modern realities require the application of an increasingly in-depth, integrated and detailed understanding of the territorial management of environmental development, the ecology of the management system is particularly acute in mining regions, due to the significant damage that the mining industry causes to the environment. Russia is a state whose export potential is largely determined by the export of extracted minerals and minerals that have undergone primary processing. Mining leads to an inevitable increase in anthropogenic impact on regional ecosystems, and hence on global environmental processes. The high importance of mining for the economic development of individual states (including Russia) and the world community is beyond doubt.

In the global practice of strategic planning, such concepts as "ecosystem management" and "sustainable development" are becoming increasingly important. The concept of "sustainable development" in relation to the mining industry in the international community begins to take shape at the end of the XX - beginning of the XXI century. The relevance of this area has been confirmed by the international community. In September 2019, Chile hosted the 6th International Congress on Environment and Social Responsibility in the Mining Industry, Sustainable Mining 2019, which was attended by more than 275 participants from 16 countries [2]. (Russian representatives did not participate in the

${ }^{*}$ Corresponding author: $\underline{\text { 40882kip@mail.run }}$ 
conference). The work of the congress was devoted to pressing environmental and social issues in the global mining industry. The conference examined the key areas of development of the mining industry, formed by the international community in recent decades.

The development of a territory development strategy is the prerogative of its highest authorities. It is at the strategic level that the mission and the general goal of the development of the territory are formulated, which are then detailed in tasks and implemented through specific programs, events, allowing to achieve results. The presence and nature of events in strategic documents allows us to judge the level of interest and involvement of the authorities in solving certain issues.

\section{Materials and methods}

The need for greening management, especially in mining regions, has determined a research interest in regional strategies for socio-economic development in terms of the presence / absence in these documents of modern approaches to solving environmental problems. It seems appropriate to study the content of strategic documents of the socioeconomic development of the mining regions of the Russian Federation with a view to assessing the content of elements of environmental management of the development of territories in them.

The selection of regions specializing in mining was carried out by us in accordance with the Strategy for Spatial Development of the Russian Federation [3]. The named document highlights promising economic specializations of the regions of the Russian Federation. Moreover, in 41 regions out of 85 , mining was named as a promising specialization. In addition, for the five constituent entities of the Federation, mining is an unpromising economic specialization critical for the region's economy. Thus, the object of the study was the strategic documents of the socio-economic development of 46 constituent entities of the Federation, specializing in including mining.

In this regard, the purpose of our study is the level of environmental friendliness of strategic management in the constituent entities of the Russian Federation, classified as extractive. The scope of analysis included strategic documents of 45 constituent entities of the Russian Federation (the Kursk region did not present an actual strategy on the Internet).

As criteria for the analysis of the environmental friendliness of strategic management, we took the following: K1 - the presence of environmental goals among the main strategic guidelines for the development of the region; K2 - the availability of measures to ensure environmentally-oriented economic growth and the introduction of environmentally effective innovative technologies; K3 - the presence of measures to reduce the negative impact on the environment; K4 - the presence of measures to preserve the environment.

\section{Results and discussion}

The study showed the following. Goal-setting is the foundation of strategic management. Criterion K1 allows you to study the priorities of regional development, promising areas of effort. By the nature of the strategic goals, one can judge the nature of the activities undertaken in the region in the next few years. The analysis showed that as part of the main strategic goals, only 23 producing regions have environmental goals and development priorities. That is, $51 \%$ of the producing regions do not currently focus their further development on the priority solution of environmental issues, on "green" standards in the management of the territory. It should be noted a significant difference in approaches to the formulation of strategic environmental goals in the regions. 
It should be noted a significant difference in approaches to the formulation of strategic environmental goals in the regions. So, 17 regions have identified environmental goals as development priorities. For example, the mission of the Republic of Buryatia is formulated as a trinity of the natural environment, people and the economy. In one region - the Astrakhan region - for strategic purposes, a narrow region was identified - the reproduction of natural resources of the Volga-Caspian basin. In five regions, environmental issues are an integral part of the strategic objectives of improving the quality of the living environment for humans.

Ensuring environmentally oriented economic growth and the introduction of environmentally efficient innovative technologies (criterion K2) in most constituent entities of the Russian Federation involves the development of the production of environmentally safe and biologically high-grade agricultural products considering regional specifics (animal husbandry, crop production, etc.). In addition, the development of recreational and health tourism can be attributed to the $\mathrm{K} 2$ criterion. The border regions are planning the development of tourism as the core of an export-oriented health cluster (Kamchatka Territory, Magadan Region, the Republic of Karelia and others), the internal regions are mainly focused on the development of domestic tourism (Irkutsk Region, Altai Territory, the Republic of Buryatia and others). Strategic development activities of the territory management system aimed at using environmentally friendly innovative technologies are contained in $24(53 \%)$ strategies of mining regions. At the same time, only in three strategies - 7\% (Arkhangelsk region, Nenets Autonomous Okrug) the corresponding criteria for evaluating the implementation of these activities are provided. It should be noted that in 13 regional strategies (29\%) specific actions and areas of action were named, 8 regions $(18 \%)$ limited themselves to a description of areas of work for the greening of territorial development management. In almost all regions, the development of an environmental monitoring system in one form or another is envisaged.

Measures to reduce the negative impact on the environment (criterion K3), in most strategies, are reduced, firstly, to the restoration of disturbed ecological systems, and secondly, to the efficient management of waste. The strategies of 13 regions (29\%) include measures to reduce accumulated harm, and 26 strategies $(28 \%)$ - to ensure the efficient management of waste. Most strategies include measures to reduce harmful emissions and improve the quality of drinking water. Almost all activities of this unit have a mechanism for monitoring their implementation through the formation of a system of relevant indicators. It should be noted that in some regions there are no indicators and indicators of waste management, the prospective development of non-waste production.

Environmental conservation measures (criterion K4) in regional strategies include the conservation and creation of new specially protected natural areas (18 regions or 40\%) and the conservation and restoration of forests (11 regions or $24 \%$ ). All events of this block are confirmed by indicators. It should also be noted that in the constituent entities of the Russian Federation that have unique ecological objects or a special territorial location, considerable attention is paid to the problem of restoring the damaged natural ecological systems of these natural objects. This distinguishes the strategies of the Kamchatka Territory (focusing on the resources of the Pacific ecosystem), Astrakhan Oblast (Caspian), Murmansk Oblast (Arctic zone), Irkutsk Oblast (Baikal). At the same time, insufficient attention is paid to the problem of reclamation of disturbed space, bioremediation of contaminated territories (in the strategies of the Orenburg and Kemerovo regions these areas are identified as separate types of activity). The border subjects of the Russian Federation are oriented towards participation in international cooperation programs in the field of environmental protection. So, the Astrakhan region - programs for the protection of the Caspian, Magadan region - in the programs of the Arctic Council and the Council of the Barents / Euro-Arctic Region (BEAC). 
Analysis of strategic planning in the mining regions of Russia with a further review of the practice that has developed in the world community.

In the 1990s, wider information access and increased social activity of local communities in various countries led to widespread allegations of human rights violations in the areas where mining enterprises are located [4]. Social and environmental issues have led to clashes and conflicts between mining companies and local communities (including casualties). The need to solve these problems entailed several international initiatives in the field of mining. One of the first steps was taken at a conference organized by the World Bank in 1997 on the problems of implementing projects in the mining industry. Canadian mining expert James Cooney introduced the concept of a "social license to operate", the essence of which is that a company receives "approval" at various levels (from acceptance to permission) of the local community for the company's activity[5].

Another step towards sustainable interaction between mining enterprises and local communities was the MMSD project "Mining, Minerals and Sustainable Development" (MMSD), implemented with the participation of the independent international organization International Institute for Environment and Development. The key objectives of the mining industry, according to the MMSD project, are: 1. the viability of the industry, 2. control, use and management of land, 3. minerals and economic development, 4. local communities and mines, 5. mining, minerals and the environment environment, 6 . integrated approach to the use of minerals, 7. access to information, 8. artisanal and small-scale mining, 9. sector management [6].

In 2001, the International Council for Mining and Metallurgy (ICMM) was created [7]. The Council unites 26 mining and metallurgical companies and 35 regional and raw material associations present in 59 countries. Russian companies do not participate in ICMM. The activities of ICMM are focused primarily on solving environmental and social problems, labor safety problems.

In 2003, the world community launched another initiative in the extraction of mineral resources The Extractive Industries Transparency Initiative (EITI) and sustainable development of underground mining regions. The Extractive Industries Transparency Initiative (EITI) is the global standard for managing oil, gas and mineral resources. He seeks to address key management issues in the extractive sectors. The EITI standard requires information on the entire value chain of the extractive industry from the point of extraction to before revenue flows through the government and contributes to the economy. This includes how licenses and contracts are distributed and registered, who are the beneficial owners of these operations, what are the tax and legal arrangements, how much is paid, how much is paid, where the income is distributed, and its contribution to the economy, including employment. The EITI standard is implemented in 52 countries. Each of these countries is obliged to publish an annual EITI Report with disclosure of information on: contracts and licenses, production, revenue collection, income distribution and social and economic expenses [8]. The Russian Federation has not joined the EITI standard. In recent decades, the concept of ecosystem management has also been introduced in UN documents, primarily in the United Nations Environment Program (UNEP). In the UNEP Medium-Term Strategy 2010-2013 ecosystem management has become one of UNEP's six priority areas [9].

Currently adopted IFC [10] activity standards, which are an international benchmark for determining environmental and social risks, are widely used in the activities of various subjects of socio-economic relations and environmental and social issues management. IFC standards cover the following aspects: 1) assessment and management of social and environmental issues; 2) staff and labour; 3) prevention and elimination of negative impact on the environment; 4) health and safety; 5) the use of land for industrial purposes and the 
relocation of people in connection with this; 6) conservation of biodiversity and rational use of natural resources; 7) indigenous peoples; 8) cultural heritage.

\section{Conclusion}

The key areas of international development of the mining industry and mining territories have become: environmental safety, financial and technological transparency of companies, resource conservation, company interaction with local communities.

According to the analysis of the level of environmental friendliness of strategic management in the constituent entities of the Russian Federation classified as extractive, we can conclude that the general pattern is an increase in the number of environmental parameters in the strategies of the "latest generation", in regional programs drawn up for the period up to 2030-2035. At the same time, in the analyzed strategies of the mining regions, there are no development indicators that are priority for the international community: financial and technological transparency of companies, resource saving, interaction of companies with local communities.

\section{References}

1. D.E. Pataki, Front. Ecol. Evol., 3, 57 (2015)

2. M. Tyulenev, Y. Lesin, E. Tyuleneva, E. Murko, E3S Web Conf., 15, 02003 (2017)

3. Government of the Russian Federation of February No. 207-r 13 (Russian Gazette, Moscow, 2019)

4. U. Gankhuyag F. Gregoire. Managing mining for sustainable development (2018)

5. K. Moffat, A. Zhang. The paths to social license to operate: An integrative model explaining community acceptance of mining (2018)

6. S. Markov, J. Janočko, M. Tyulenev, Y. Litvin, E3S Web Conf. 105, 01021 (2019)

7. M. Tyulenev, S. Markov, E. Makridin, Y. Lesin, V. Gogolin, E3S Web Conf., 105, 02022 (2019)

8. Extractive Industries Transparency Initiative (EITI, Brussels, 2019)

9. J. Ahern, S. Cilliers, J. Niemelä. Landsc. Urban Plan., 125, 254-259 (2014)

10. IFC Policies-Standards (EITI, Brussels, 2012) 